\title{
Donald Baird and his discoveries of Carboniferous and early Mesozoic vertebrates in Nova Scotia
}

\author{
Hans-Dieter Sues ${ }^{1 *}$, Robert W. Hook ${ }^{2}$, and Paul E. Olsen ${ }^{3}$ \\ 1. Department of Paleobiology, National Museum of Natural History, Smithsonian Institution, MRC 121, P.O. \\ Box 37012, Washington, DC 20013-7012, USA \\ 2. Vertebrate Paleontology Laboratory, The University of Texas at Austin, Austin, Texas 78758, USA \\ 3. Lamont-Doherty Earth Observatory of Columbia University, 61 Rt. 9W, Palisades, \\ New York 10964-1000, USA \\ *Corresponding author $<$ suesh@si.edu $>$
}

Date received: 23 March 2013 g Date accepted 08 April 2013

\begin{abstract}
Donald Baird (1926-2011), an influential and innovative vertebrate paleontologist with a scientific career spanning nearly 50 years, had an exceptional breadth of expertise in the study of late Paleozoic and Mesozoic vertebrates and their life traces. Beginning in 1956, Baird conducted fieldwork in the Carboniferous and Triassic-Jurassic of Nova Scotia, making a total of 21 trips in 30 years. His many scientific contributions include the discoveries of important assemblages of Carboniferous vertebrates as well as an unexpectedly diverse record of early Mesozoic tetrapods and their trackways in the province. Baird also encouraged and supported fieldwork by other vertebrate paleontologists as well as amateurs in Nova Scotia and elsewhere. His career-long commitment to the vertebrate paleontology of the province was instrumental in establishing it as an important source of fossils of Carboniferous and early Mesozoic continental vertebrates.
\end{abstract}

\section{RÉSUMÉ}

Donald Baird (1926-2011), paléontologiste des vertébrés influent et novateur dont la carrière scientifique s'est échelonnée sur près de 50 ans, a acquis un savoir-faire exceptionnel dans l'étude des vertébrés du Paléozoïque tardif et du Mésozoïque et des vestiges de leur vie. À partir de 1956, M. Baird a mené des études sur le terrain du Carbonifère et du Trias-Jurassique en Nouvelle-Écosse, où il s'est rendu au total 21 fois en 30 ans. Ses nombreuses contributions scientifiques comprennent notamment les découvertes d'importants assemblages de vertébrés du Carbonifère ainsi que d'un nombre étonnamment diversifié de tétrapodes du Mésozoïque inférieur et de leurs traces dans la province. M. Baird a en outre encouragé et soutenu les études sur le terrain d’autres paléontologistes des vertébrés et d'amateurs du domaine en Nouvelle-Écosse et ailleurs. Pendant toute sa carrière, il s'est consacré à la paléontologie des vertébrés de la province, ce qui a contribué à la réputation de la Nouvelle-Écosse en tant que source importante de fossiles de vertébrés continentaux du Carbonifère et du Mésozoïque inférieur.

[Traduit par la redaction] 


\section{INTRODUCTION}

Donald Baird (1926-2011) published on a wide range of subjects in vertebrate paleontology, many of which pertained to the late Paleozoic and Mesozoic of eastern North America. Starting in the 1950s, he conducted fieldwork in Nova Scotia and contributed directly or indirectly to numerous studies of Carboniferous and Triassic-Jurassic vertebrate fossils and trackways from the province. The collections he made over a period spanning three decades included discoveries that would highlight the importance of the fossil record from Nova Scotia for future research in vertebrate paleontology. Yet, because Don never published a review paper or memoir, the breadth and significance of his efforts are not widely appreciated. As individuals who collaborated with Don and who benefitted greatly from his remarkable intellectual generosity, we present here a retrospective of his Nova Scotian work.

An avid historian, Don was keenly interested in the pioneering era of vertebrate paleontology in North America, which began with Thomas Jefferson's "great claw" from Virginia at the end of the eighteenth century. Although the founders of American vertebrate paleontology Joseph Leidy, Edward Drinker Cope, and Othniel Charles Marsh - concentrated initially on fossils from the eastern United States, the opening of the American West provided unparalleled opportunities for exploration, of which Cope and Marsh energetically availed themselves. The early history of paleontological research in Canada was similar: seminal reports of trackways and tetrapod fossils in the Pennsylvanian of Nova Scotia by leading workers in the mid-nineteenth century (e.g., Lyell and Dawson 1853; Owen 1854; Dawson 1863, 1882, 1894) were largely eclipsed by discoveries of richly fossiliferous, well-exposed late Mesozoic and early Cenozoic rocks in western Canada starting in the 1870s. In both countries, the westward shift of paleontological exploration was accompanied by an unfortunate decline of work in eastern provinces and states where, for nearly a century, most discoveries would be made by chance rather than as the result of dedicated search. Unlike research programs based upon systematic prospecting of vast western exposures, fossil hunting in the populated or densely vegetated eastern realm was limited to quarries, mine dumps, railroad and highway cuts, building sites, and, especially in the case of Nova Scotia, coastal outcrops.

Unlike most of his colleagues, Don devoted his career to the study of the important but less fossil-rich late Paleozoic and Mesozoic continental deposits he found in the eastern United States and Nova Scotia. He formally entered vertebrate paleontology through geology and used his geological acumen to find and collect fossil deposits that others would have either overlooked or disregarded as sources of mere scrap. In addition, the curious circumstances of his museum position at Princeton University allowed Don to adopt a long-term approach that was very well suited to working Nova Scotia's vertebrate-bearing deposits, the majority of which yield only rare vertebrate fossils that require substantial preparation effort. Today, the material of fossil vertebrates from Nova Scotia that he patiently and painstakingly brought to light represents a significant part of a record that is stratigraphically well constrained and that includes numerous taxa not found elsewhere. Our objective is to document Don's efforts, and so make plain his substantial but underappreciated contributions to the vertebrate paleontology of Nova Scotia.

Don's contributions are best understood in the context of his long and multifaceted career, and so we present a short biography before discussing his endeavors in Nova Scotia. We emphasize Don's early career experiences, which provided him with unique skills and knowledge that are of particular significance to his later work in the province. Our account is based upon his published work as well as his unpublished notebooks, which total 691 pages and cover fieldwork, museum visits, and other professional activities from March 1953 through August 1998. The notebooks and Don's voluminous scientific correspondence were donated to the Society of Vertebrate Paleontology Archive in August 2011 (Smithsonian Institution Archive Accession No. 12107). Any quotes without reference are either from our association with Don (totaling some 114 years) or from his notes.

Institutional abbreviations (preceding catalogue numbers) used in the text are as follows: MCZ, Museum of Comparative Zoology, Harvard University, Cambridge, Massachusetts; NSM, Nova Scotia Museum of Natural History, Halifax, Nova Scotia; YPM VPPU, former vertebrate paleontology collection of Princeton University, now housed at the Peabody Museum of Natural History, New Haven, Connecticut.

\section{BIOGRAPHICAL SKETCH}

Donald Baird was born on 12 May 1926 in Pittsburgh, Pennsylvania, to Mary Alma Barton Johnson Baird and George Mahaffey Patterson Baird of Scottish and northern Irish descent. Young Donald was interested in science and history and had an amazing appetite for knowledge he read nearly every book in his father's large library and learned Latin, Greek, and French. As a teen he won awards at science fairs and volunteered in the Sections of Vertebrate Fossils and Archaeology at the Carnegie Museum of Natural History in Pittsburgh. After graduation from high school in 1943, Don enrolled at the University of Pittsburgh but soon left for the US Army and was deployed to the 609th Tank Destroyer Battalion shortly after the unit had crossed the Rhine. He returned to the University of Pittsburgh following 
his honorable discharge and completed undergraduate studies in biology and geology in 1947. During this time he also worked briefly for the Pennsylvania Topographic and Geological Survey, as well as for the Carnegie Museum of Natural History. While at Carnegie, Don met Helen Lucille Bailey, who also had earned an undergraduate degree in geology from Pittsburgh and shared a keen interest in museum work. They married on Valentine's Day of 1948 and would have two children, Andy and Laurel. Lucy and Don frequently did fieldwork together in the 1950s, and she contributed important specimens and many significant geological observations. Her untimely death in 1963 was a tragic loss.

The spring of 1948 found Don and Lucy at the University of Colorado in Boulder, where both studied geology, graduating with master's degrees in 1949. While in Colorado, Don started his career-long study of fossil footprints, which eventually would include investigations of material from Nova Scotia. He became acquainted with Frank Peabody, who was introducing rigorous scientific methods to the study of trackways. Prior to Peabody's work, footprints and trackways were generally treated as geological curios of little scientific import. Peabody's (1948) classic monograph on Triassic tetrapod tracks from the American Southwest set a new standard, replete with a glossary of mostly new terms and a quantitative approach that is still used, almost without modification. Peabody was a brilliant researcher whose talents spanned many fields (Camp 1958); his untimely death was something Don always rued deeply.

Just as Peabody brought rigor to the study of tracks, Don brought common sense to collecting them. Traditionally, the collection of trackways had involved backbreaking chiseland-hammer work or the making of plaster casts, with rarely satisfactory results. Having worked in Pittsburgh with the artist Ottmar F. von Fuehrer, Don knew of the remarkable versatility of a new latex rubber compound that von Fuehrer had developed for exhibit work (Baird 1951). Using latex, which could be thinned to about the consistency of a milk shake for molding and casting and which set overnight, Don started to make molds or positive casts of footprints. The high-fidelity latex casts were lightweight and ideally suited for detailed examination and photography under low angle illumination.

In late 1949, Don accepted a curatorial position at the University of Cincinnati's geology museum. Though he was paid little and the museum was but a modest entity, this appointment allowed him to continue his work on Paleozoic trackways and embark on the study of PermoCarboniferous vertebrate fossils from the mid-Continent and the Appalachians. Most significantly, a geology graduate student at Cincinnati gave him directions to the famous Pennsylvanian vertebrate locality of Linton, Ohio, where fossil fishes and tetrapods had first been recovered from an underground coal mine in the 1850s. Although the mine had been abandoned in 1921, a large spoil pile marked the site of the former coal tipple (Hook and Baird 1986). Don found that some of what the coal company had rejected was the fossiliferous cannel coal that contains the skeletal remains of scores of vertebrate taxa and, as he would later demonstrate, an overlooked assemblage of freshwater and terrestrial invertebrates.

Following his initial collecting trip to Linton in 1950, Don realized that most of its supposedly well-known vertebrate assemblage was in dire need of revision. Unable to identify some of his finds from existing literature, he sent a few specimens to Alfred S. Romer at the Museum of Comparative Zoology at Harvard. Early in his career, Romer (1930) had published a major revision of the diverse Linton tetrapod assemblage, but by 1950 when Don contacted him, Romer was one of the world's leading vertebrate paleontologists and had moved on to other areas of research (Colbert 1982). Romer did, however, express a sincere interest in Don's work on late Paleozoic trackways and welcomed his inquiry regarding graduate study in vertebrate paleontology at Harvard.

Romer's indifference towards the new discoveries from Linton motivated Don to develop a new approach to the preparation and study of fossils preserved in cannel and similar coals. Using basically the same technique he had successfully applied to trackways, Don started to prepare Linton fossils by a method that combined acid etching with latex micro-casting. The resulting latex casts became known as peels, and the procedure was such an innovation that the leading scientific weekly Science would later publish a report on the technique (Baird 1955). Over a period of several decades, Don prepared nearly every significant specimen from Linton in this manner, which lead to a renaissance in the study of Pennsylvanian vertebrates from Linton and comparable assemblages. Beyond preparing specimens, however, Don became expert in the identification of late Paleozoic vertebrates, often based upon exceedingly incomplete material, a skill that would serve him well in later studies of vertebrate fossils from Nova Scotia.

Don left Cincinnati in late 1951 to pursue doctoral studies with Romer. He had planned to continue his work on Permo-Carboniferous tracks, but within a year decided that footprints of Mesozoic reptiles, far more plentiful than those of the Paleozoic and of broader interest, were going to be his dissertation topic. He visited numerous institutions on the East Coast, making latex peels of their holdings of Paleozoic and Mesozoic tracks. At Yale, Don became acquainted with Richard S. Lull. Though well into his $80 \mathrm{~s}$, Lull was still active and the leading authority on Mesozoic footprints from the Connecticut Valley, which he had first reviewed early in his career (Lull 1904). He was so pleased with the enthusiastic young man from Harvard that he gave him unrestricted access to the rich collections of the Peabody Museum of Natural History. No early Mesozoic 
footprints from Nova Scotia were included in Don's study because none were known at the time but, like his formative work on late Paleozoic vertebrate remains and trackways from the Ohio Valley, his dissertation research would foster subsequent discoveries from the province.

In 1954, Don published his first paper on Triassic tetrapod tracks (Baird 1954). It included what would become a hallmark of his contributions: he demonstrated that two specimens held by two different institutions and said to be from different states (Pennsylvania and New Jersey) were, in fact, part and partial counterpart of the same specimen, the type of the ichnospecies Chirotherium lulli, most likely made by pseudosuchian reptiles and collected from Milford, New Jersey. Such discoveries were second nature to Don who had an eidetic memory and a keen eye for details, even incorporating such minutiae as mudcrack patterns and raindrop impressions when it came to understanding and relating trackway specimens.

In 1955, along with completing his dissertation on Connecticut Valley trackways, Don undertook an extensive summer field campaign for the Museum of Comparative Zoology on the west side of the Appalachians in a season that was a template for Nova Scotian explorations the following year. With the able assistance of Lucy he assimilated existing geological maps and reports, visited known fossil localities, made collections, took detailed field notes, and developed a search image for additional vertebrate occurrences. The Bairds concentrated on Carboniferous formations but made their most significant discovery in rocks regarded as Lower Permian: a bonebed in the Nineveh Limestone at Clark Hill in Monroe County, Ohio (Berman 1978). This occurrence alerted Don to the paleontological potential of comparable deposits of freshwater limestones elsewhere in the Upper Ohio Valley and, later, in Nova Scotia.

Don's work in the Ohio Valley in 1955 was funded by a grant Romer had received from the then-young National Science Foundation. The objective was to find early tetrapods and, with the talents of Don and others at the Museum of Comparative Zoology, Romer believed it was only a matter of looking at more rocks. The next summer, Don returned to the Appalachians, working mainly with Arnold D. Lewis, to do reconnaissance work in Devonian through Mississippian rocks of Pennsylvania. Joined by Romer in the second week, they found an amazing quantity of fossil vertebrate remains - significant material of acanthodians, arthrodirans, chondrichthyans, dipnoans, and tetrapodomorph fishes - but it was marine in origin and did not include any tetrapod fossils. This work gave Don valuable experience in recognizing sedimentological and paleontological evidence for distinguishing between marine and freshwater environments and fossil assemblages, additional useful knowledge he later would take to Nova Scotia.

The MCZ Appalachian party returned to Massachusetts for only 10 days before departing with others for Nova
Scotia, as discussed in the next section. Don was able to stay at the MCZ as an assistant curator with support from the Agassiz Fund until 1957 (Fig. 1). Though he had pursued many avenues for employment throughout his graduate student days, he was not to have success until he was invited to Princeton University in March 1957 to meet Glenn L. Jepsen, Director of the Princeton Museum of Natural History, then a renowned paleontological institution. Jepsen was looking for someone to renovate the museum and recognized in Don a person with the knowledge, ambition, and skills required for the job.

Unfortunately, Jepsen and Don were polar opposites in terms of personality, and their association would quickly turn adversarial. Yet, from his first days at Princeton, Don demonstrated his worth and made friends with nearly everyone in the geology department and all in the museum and lab. As Don built his reputation as a leading museum curator and vertebrate paleontologist, Jepsen could not afford to lose such a respected, hard-working, and talented associate. Despite his personal difficulties with Jepsen, the Princeton Museum proved to be an ideal environment for Don's work in Nova Scotia: it provided some institutional

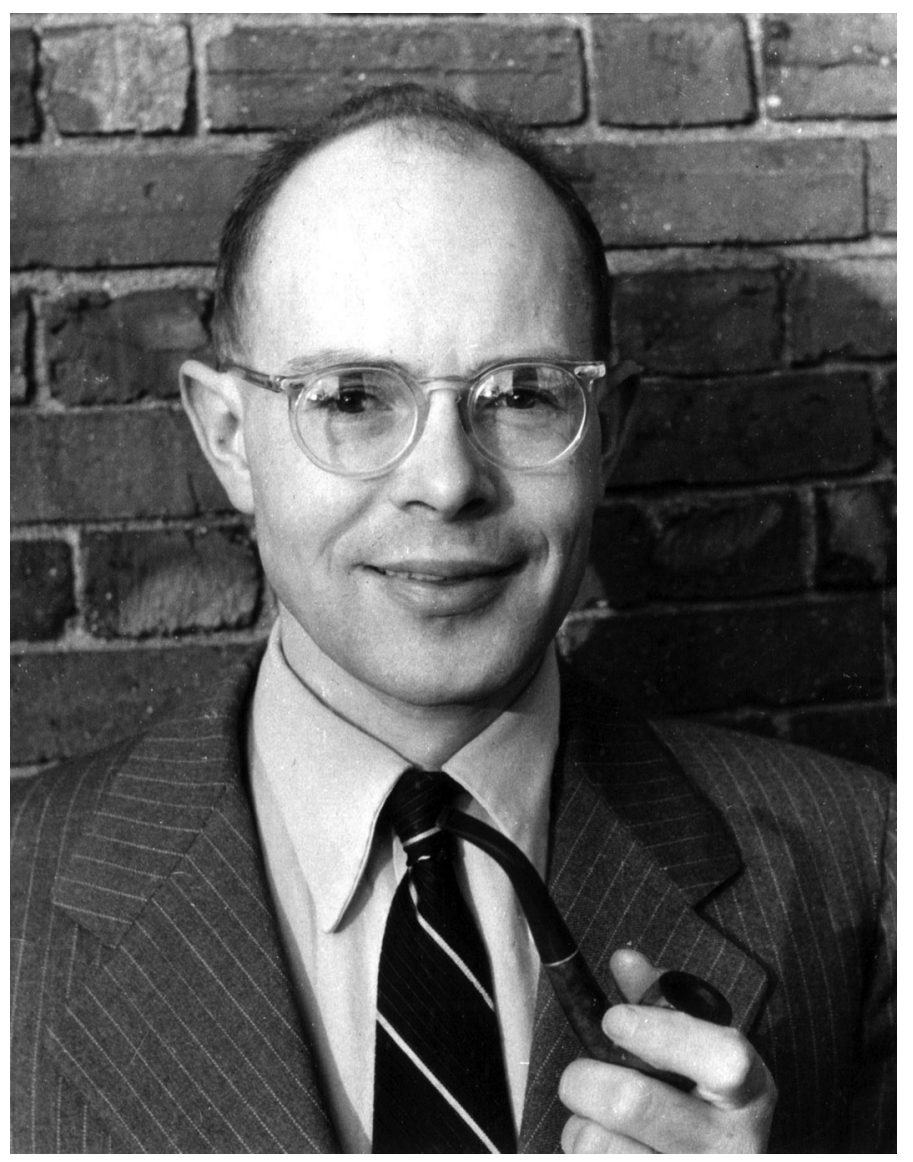

Figure 1. Dr. Donald Baird, Assistant Curator, Museum of Comparative Zoology, January 1956. Courtesy of A. Baird. 
support for fieldwork as well as a state of the art preparation lab, which Don managed and where he trained many students and full time technicians. Furthermore, Don was under no pressure to publish research papers or apply for grants. All these factors allowed him to take a long-term approach that focused on the preparation of difficult material from Nova Scotia and the building of small but significant collections.

During the next three decades at Princeton, Don would design and build museum exhibits, entertain school groups, promote the Princeton Junior Museum (one of the first community oriented, hands-on museum programs in the United States), host visiting researchers, prepare fossils, train technicians, arrange for loans and exchanges of specimens, and curate collections. Over the years, his curatorial responsibilities grew to include not just fossil vertebrates, but considerable collections of fossil invertebrates and plants and even important holdings in archaeology and anthropology. After Jepsen died in 1974, Don was appointed Director of the museum. The Department of Geological and Geophysical Sciences also awarded him the largely honorary title of Research Paleontologist in 1975.

Don's final task at Princeton was the relocation of the museum's world-renowned collections. This sad event had its political beginnings in the 1960s and was finalized in the mid-1980s as the geology department and university moved away from paleontological research and the maintenance of a public natural history museum. The collection of fossil vertebrates was transferred to the Peabody Museum of Natural History of Yale University, along with some holdings of fossil plants. Don arranged transfers of other collections to more than a dozen other institutions, including the National Museum of Natural History of the Smithsonian Institution. In June 1988, Don retired from Princeton and returned to his hometown of Pittsburgh.

When Don left Princeton, he took with him a considerable amount of material of fossil vertebrates that he had collected in Nova Scotia and had earnest plans to finish several descriptive papers that had languished over the years. A few years prior to retirement, however, he had learned of the discovery of a Pennsylvanian vertebrate assemblage at Five Points, south of Youngstown, in Mahoning County, Ohio. The deposit was a cannel coal very similar to, but somewhat older than, Linton, and the source was a surface mine that was in its last days of operation. In the summer of 1989, Don purchased all 220 tons of the last stockpile and, together with one of us (RWH), started what was to be a two-year salvage program supported by a grant from the National Geographic Society. During the second year, some 800 additional tons of the same fossiliferous cannel coal were found on the property of the East Fairfield Coal Company, for whom RWH was working as a consulting geologist. The company generously donated the material and provided storage space for the small mountain of coal to be examined by Don and RWH, a process that was eventually completed in August 1998. Throughout the nine-year period and for several years afterwards, Don used his technique of acid etching and latex casting to patiently prepare and identify approximately 1,700 specimens from Five Points, all in the basement of his Pittsburgh townhouse. The collection, representing at least 31 vertebrate taxa, is divided almost evenly between fishes and tetrapods (Hook and Baird 1993) and provides a rich source of data for future studies of the diversity and paleoecology of Pennsylvanian vertebrates.

After fossil collection at Five Points ended, Don never returned to the field but continued work on various research projects in his basement study-cum-laboratory. In his last years, as his correspondence and correspondents waned, friends and fellow researchers would call or visit his house. They would find Don alert and sharp as ever but increasingly frail. Although the Five Points project had partially coopted his anticipated plans for research on fossil vertebrates from Nova Scotia in his retirement years, he collaborated with two of us (H-DS, PEO) and others in the completion of several papers based upon his Nova Scotian discoveries.

\section{FIELDWORK AND DISCOVERIES IN NOVA SCOTIA}

\section{Carboniferous vertebrates}

In the summer of 1956, Romer organized a field season to search for early tetrapods in Nova Scotia with financial support from the National Science Foundation. The target was the province's Carboniferous strata, which, with the exception of the world-famous Joggins section (Dawson 1882; Calder et al. 2006), had produced only two tetrapod specimens from an underground coal mine and vertebrate trackways and occasional scraps of bone from its scenic coastal exposures (Owen 1854; Watson 1926; Beaumont 1977; Sarjeant and Mossman 1978) (Fig. 2). Don would later observe that " $\mathrm{t}$ ]his Acadian reconnaissance shaped my field activities for decades to come" (Baird 1997, p. 24).

Romer divided the MCZ field party into three groups to work the known fossil vertebrate localities and prospect for new deposits. In addition to Romer and his wife Ruth, participants comprised Don and Lucy with their son Andy, Romer's research assistant Nelda E. Wright, and paleontological preparators Richard Van Frank, Arnie Lewis and James A. Jensen.

The party first worked at Joggins before going separate ways. During July, Don and Lucy prospected outcrops at Parrsboro and Horton Bluff between rain showers and visits to mostly non-productive coastal exposures, then returned to Parrsboro to make latex molds of trackways as the weather improved. Late in the month, Lucy discovered an upright lycopsid stump at Parrsboro that contained a small temnospondyl skull, the first tetrapod fossil ever 


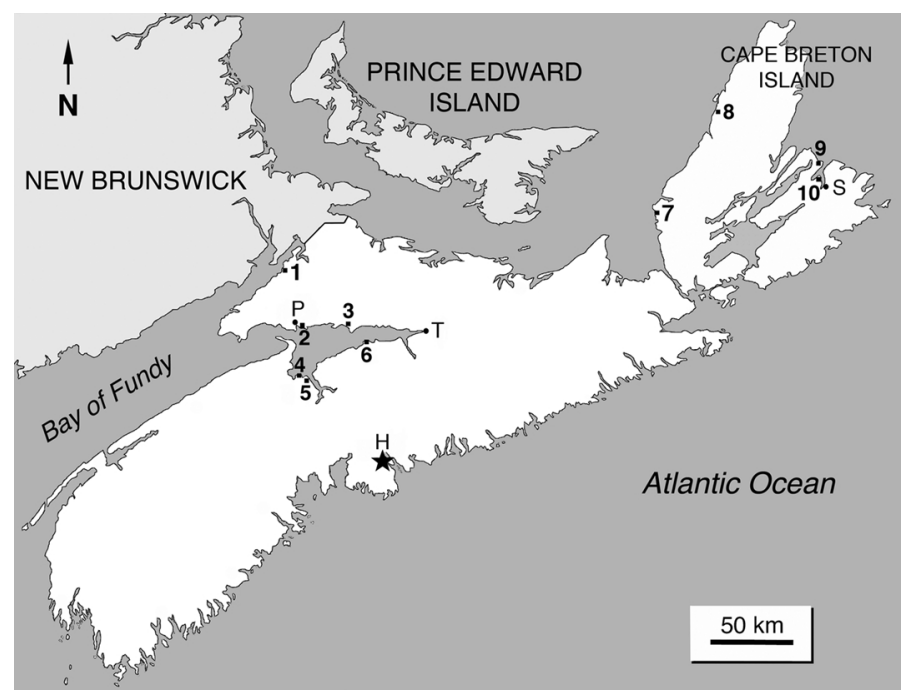

Figure 2. Outline map of Nova Scotia and adjoining regions with fossil vertebrate localities discovered and/ or explored by Don Baird: 1, Joggins; 2, Wasson Bluff; 3, Lower Economy; 4, Evangeline Beach; 5, Horton Bluff; 6, Burntcoat; 7, Port Hood; 8, Grand Étang; 9, Florence; 10, Point Edward. Abbreviations for city and town names: $\mathrm{H}$, Halifax; P, Parrsboro; S, Sydney; T, Truro.

found at a locality known for its trackways. Milner (1982) considered this specimen (MCZ 2774) possibly referable to Dendrerpeton, which had first been discovered by Dawson and Lyell at Joggins in 1852 (Lyell and Dawson 1853).

In early August, the MCZ field party reunited briefly at Crystal Cliffs near Antigonish before moving on to Cape Breton Island (Fig. 3). The Bairds worked along the northwest coast of the island, finding and molding trackways and collecting fragmentary remains of Carboniferous vertebrates. The most significant locality they discovered was an exposure of freshwater limestone in the Pomquet Formation (Mabou Group; Mississippian: Serpukhovian: Arnsbergian) at Grand Etang that would yield fish and fragmentary tetrapod remains (Baird 1978a; Holmes et al. 1995). By mid-August, Don and Lucy turned east to meet up with the others, who had just discovered tetrapod remains in upright lycopsid tree stumps near Florence, on the northeastern side of the island (Fig. 2).

The Florence stump assemblage, discovered by Arnie Lewis, would prove to be the most important find of the 1956 fieldtrip to Nova Scotia, even though it was too young to sate Romer's desire for fossils of genuinely ancient tetrapods. The fossil locality is in an abandoned surface mine (Dominion Coal Company No. 7) in the Sydney Mines Formation (Cumberland Group; Pennsylvanian: Moscovian), about $2 \mathrm{~km}$ north of Florence. Younger in age than the famous assemblage from the lycopsid stumps at Joggins (Pennsylvanian: Bashkirian: Langsettian), vertebrate fossils from Florence generally are better preserved than those from Joggins and more or less coeval with the Linton cannel coal, so that meaningful comparisons between the Florence and Linton assemblages could be made. Although collecting at the strip mine proved challenging - the bonebearing tree stumps were exposed in a high wall of a strip cut, the floor of which is flooded (Fig. 4) - Don and others would repeatedly revisit the locality in later years to recover additional fossils. Carroll (1967, 1969), Reisz (1972), Rieppel (1980), Klembara (1985), and Godfrey and Holmes (1995) have published detailed studies of individual tetrapod taxa from Florence.

On the return trip from the Sydney area, the Bairds continued to find remains of Carboniferous freshwater fishes and abundant tetrapod trackways. Don carefully recorded stratigraphic observations and locality data that he would use for future fieldtrips. He realized that the geology of Nova Scotia was much more complex than anything he had studied previously, and although he had assembled the appropriate literature and maps for the trip, he found the generalized nature of earlier geological reports insufficient for his research.

During the 1959 field season Don undertook fieldwork with William F. Take, then Curator of Geology at the Nova Scotia Museum of Science in Halifax. They prospected Carboniferous exposures where, in the Port Hood Formation (Pennsylvanian: Langsettian) near Port Hood in Inverness County, they found the anterior portion of a poorly preserved tetrapod skeleton (YPM VPPU 016982). Don and Robert L. Carroll (McGill University) would later describe this specimen as Romeriscus periallus (Baird and Carroll 1967). Interpreting it as a member of the Limnoscelidae, which were then regarded as stem reptiles, they introduced the specimen as the oldest-known reptile. A subsequent re-examination of this fossil by Laurin and Reisz (1992) failed to identify any diagnostic features in support of this assignment, and the affinities of Romeriscus remain uncertain.

Another "discovery" of the 1959 Nova Scotia trip was Eldon George, proprietor of the Parrsboro Rock and Mineral Shop. Eldon has been an exceptional collector and, during Don's many trips to Parrsboro, they usually would prospect the tremendous coastal exposures of the area together. Don and Eldon collected skull roofs of haplolepidid fishes and a fin-spine of a small acanthodian fish (Gyracanthus) that Don later described in detail (Baird 1962a, 1978a). Don introduced Eldon to collecting and identifying Carboniferous tetrapod footprints and provided latex for him to mold select trackways.

During the Nova Scotia trip of 1960, Don continued to work closely with Bill and Jane Take. On their tour of Carboniferous exposures, Don found a skull fragment near Point Edward on Cape Breton Island that he described as Spathicephalus pereger (YPM VPPU 017182; Baird 


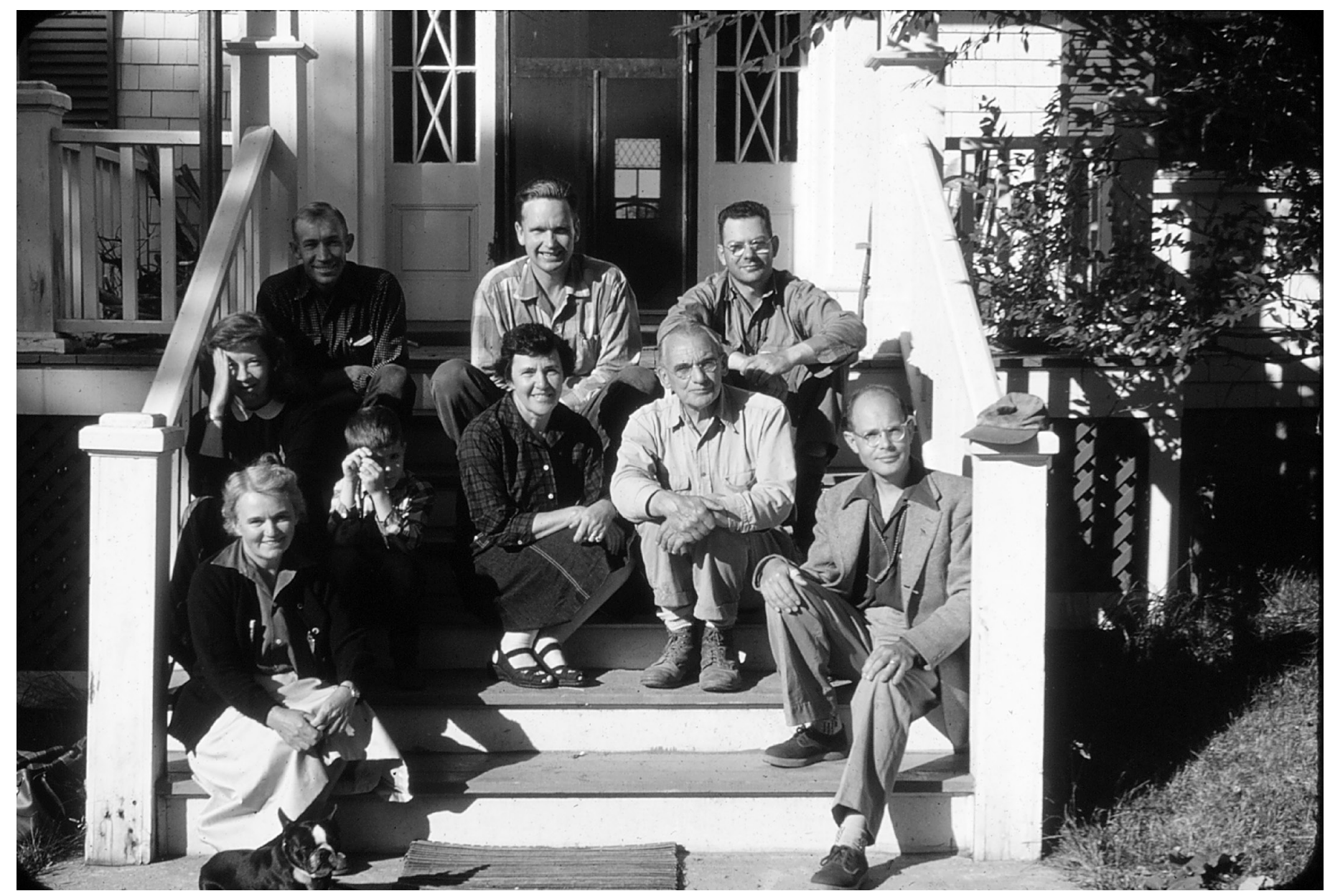

Figure 3. Museum of Comparative Zoology field party at Crystal Cliffs, Nova Scotia, August 1956. Back row, left to right: Arnie Lewis, Jim Jensen and Dick Van Frank; middle row: Lucy and Andy Baird and Ruth and Al Romer; front row: Nelda Wright (with Cookie) and Don Baird. Courtesy of A. Baird.

1962b). It was the first North American record of this distinctive stem tetrapod, the type species of which, Spathicephalus mirus, is known from the Rumbles Ironstone (Mississippian: Serpukhovian: Pendleian) of the Loanhead District near Edinburgh (Scotland). Spathicephalus has a flat, greatly expanded skull with numerous small, chiselshaped teeth (Beaumont and Smithson 1998). At Point Edward, vertebrates occur in a freshwater limestone and overlying mudstone of the Mabou Group (Mississippian: Serpukhovian: Chokierian). Although fragmentary fish remains had first been discovered there in 1913 (Carroll et al. 1972), the first tetrapod from Point Edward was collected in 1956 by Romer, who described a partial lower jaw (MCZ 2772) as ?Pholiderpeton bretonense (Romer 1958). Fifteen years later, Don would find, and recognize instantly, the counterpart of Romer's specimen, which is now regarded as an indeterminate proterogyrinid anthracosaur (Holmes et al. 1995). In 1968, Don collected an additional tetrapod specimen at Point Edward (YPM VPPU 020100), which is represented by an articulated pectoral girdle and trunk segment of a colosteid stem tetrapod similar to Greererpeton burkemorani, known mainly from the more or less coeval Mauch Chunk Group of West Virginia (Smithson 1982; Godfrey 1989).

Don first visited Horton Bluff (Fig. 2) in 1956 and made numerous subsequent visits to this Mississippian locality, the source of the earliest-known Carboniferous tetrapod remains in North America. The Horton Bluff Formation has been palynologically dated as Tournaisian (Ivorian) (Utting et al. 1989; Rygel et al. 2006). Despite the great potential of this site, tetrapod fossils are very rare and fragmentary, as well as difficult to prepare. Moreover, bones of tetrapodomorph fishes occur in the same deposit, appear to be more common, and often are difficult to distinguish from those of basal tetrapods. In their discussion of the vexing nature of the tetrapod remains from Horton Bluff, Clack and Carroll (2000, p. 1042) aptly remarked, "Rarely have so many people worked so hard and so long for so few fossils."

The exposures of the Horton Bluff Formation at Horton 


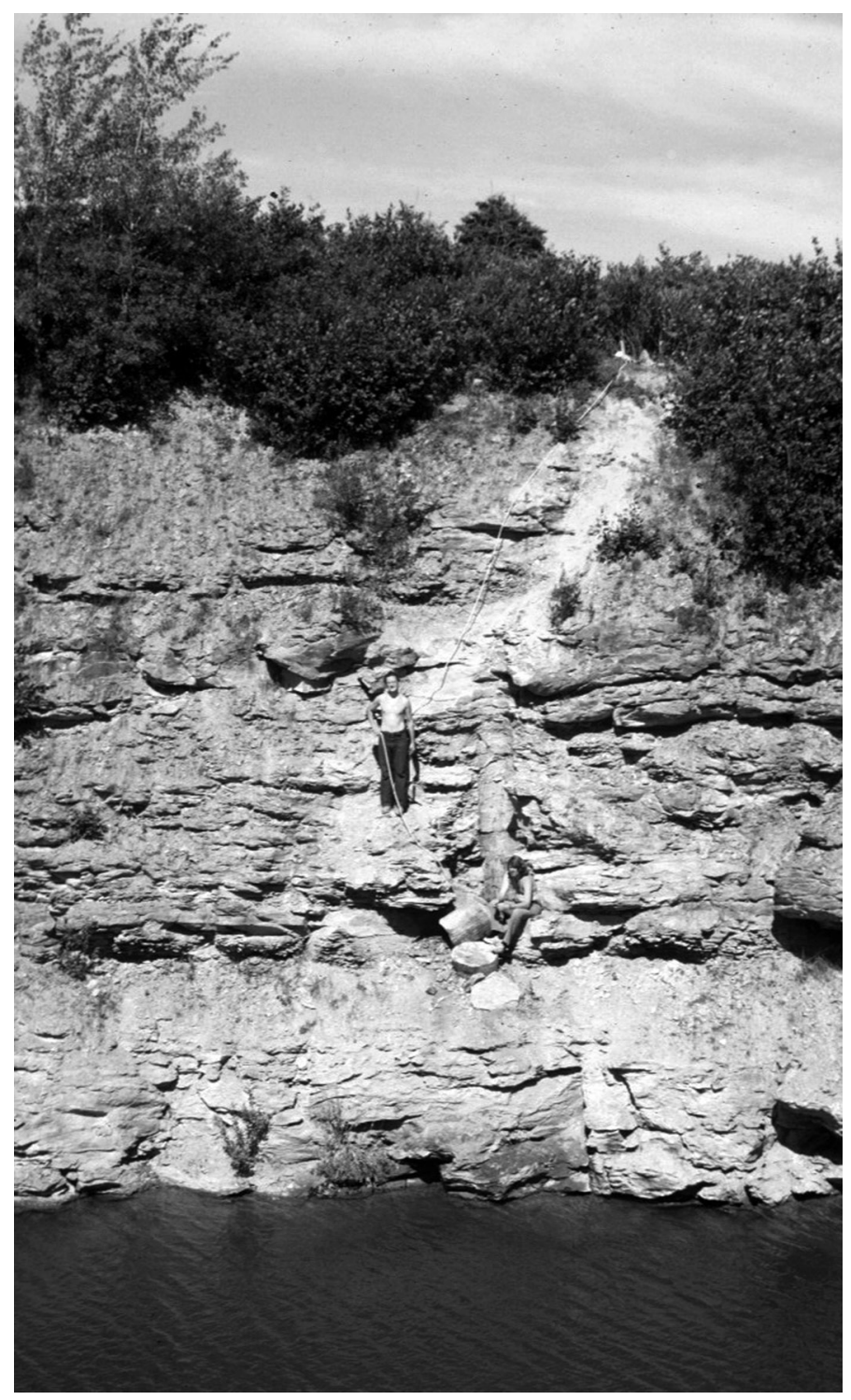

Figure 4. Collecting vertebrate-bearing upright lycopsid stump on high wall of Dominion Coal Company strip mine No. 7 near Florence, Cape Breton Island, Nova Scotia, August 1971. R. R. Reisz (mid-slope with rope) and C.P. Montgomery (at base of stump). Collection of H-DS.

Bluff (Blue Beach) had long been known for the occurrence of Mississippian tetrapod footprints, some of them attaining a print width of $20 \mathrm{~cm}$ (Sarjeant and Mossman 1978). Although Logan's original 1841 material (Hylopus logani Dawson 1882) represents Schwimmspuren (swimming traces), later collecting by Don and others documented an array of tetrapod tracks (Carroll et al. 1972). This material includes well preserved pentadactyl and tetradactyl trackways of at least six different forms of both small and rather large tetrapods that were capable of locomotion on land (Smithson et al. 2012).
Don first discovered tetrapod bones at Horton Bluff in 1966. Although he had some ideas concerning the affinities of his tantalizing finds (Carroll et al. 1972), the absence of more complete, articulated remains from Horton Bluff, as well as the dearth of comparative material from coeval strata elsewhere, prevented definitive study. Only in the last two decades has the situation begun to improve with the discovery of well-preserved, articulated Tournaisian-age tetrapod fossils in Scotland and the recovery of additional (if still only dissociated) skeletal remains at Horton Bluff. Clack (2012) most recently reviewed the tetrapod fossils from Horton Bluff. She recognized a previously unexpected diversity of taxa, including a possible reptiliomorph, a possible colosteid stem tetrapod, and a form resembling the famous stem tetrapod Ichthyostega from Late Devonian (Famennian) strata of East Greenland.

Although Don's final published contribution to the paleontology of the Maritimes is based on material from Prince Edward Island (Calder et al. 2004), the findings relate broadly to Nova Scotia and illustrate the serendipitous and often prolonged nature of Don's endeavors. While visiting Malpeque Bay, Prince Edward Island, in 1984, Elliott B. Urdang found tetrapod footprints and brought them to the attention of John H. Ostrom at Yale University, who, in turn, referred the inquiry to Don. Although he had never visited the island, Don recognized the trackways as the first footprint record for the province and encouraged Urdang to obtain further documentation, which he did in 1987. Once Don had received adequate photographs and peels of the specimens, he wrote an analysis of the material and added it to his thick file of unpublished data on Permo-Carboniferous tetrapod trackways. More than a decade would pass before John H. Calder (Nova Scotia Department of Natural Resources, Halifax) became interested in the project after consulting with Don on Nova Scotian trackways. John combined his assessment of the age of the Pictou Group in the Malpeque Bay area with Don's information to conclude that the tracks represented a latest Pennsylvanian to earliest Permian occurrence of the ichnogenera Notalacerta and Gilmoreichnus, most likely made by a basal reptile and a basal synapsid, respectively.

Otherwise, aside from comments in Carroll et al. (1972), the information that Don amassed on Carboniferous footprints from Nova Scotia has largely gone unpublished. He freely shared his considerable insights with other workers and often was acknowledged for his assistance. After Don's death, his large collection of trackway latex peels, including material from both the Paleozoic and Mesozoic and from numerous North American localities, was donated to the Peabody Museum of Natural History, along with his detailed catalogue. 


\section{Triassic and Early Jurassic vertebrates}

After Don had assumed his curatorial duties at Princeton he undertook a three-day visit to the Nova Scotia Museum of Science in Halifax in 1958. On a snowy day in late November, Bill Take introduced Don to fossil localities that he had recently discovered in the Late Triassic (Carnian) Wolfville Formation ("Evangeline Member") along the shores of the Minas Basin in the Bay of Fundy, including Evangeline Beach (Fig. 2). Don found a small incomplete skull that 40 years later became the holotype of a new taxon of procolophonid parareptile, Acadiella psalidodon (Sues and Baird 1998; NSM 996GF69.1). The informal stratigraphic terms "Economy Member" and "Evangeline Member" for units within the Wolfville Formation are used here in lieu of "lower Wolfville" and "middle Wolfville" (Olsen et al. 1989), and thus are cited in quotation marks. The need for distinguishing these two members was initially driven by Don's discovery of different Triassic faunal assemblages in different areas around the Minas Basin. The early Mesozoic succession of the Fundy Group of the Newark Supergroup comprises (in ascending order) the Wolfville Formation, the Blomidon Formation, the North Mountain Basalt, and the McCoy Brook Formation (Olsen et al. 1989).

Don returned to Nova Scotia in June 1959 and collected additional Triassic vertebrate fossils with Bill Take. With the help of Lloyd Duncanson, they reached by boat the northwest side of Boot Island, near the mouth of the Avon River east of Wolfville. From beach exposures of the "Evangeline Member" accessible only at low tide (Fig. 5), Don collected a partial procolophonid skull that would later become the holotype of Scoloparia glyphanodon (Sues and Baird 1998; NSM 996GF83.1) and an impression in sandstone of an incomplete dentary of a rhynchosaur - the first record of these presumably herbivorous archosauromorph reptiles from North America (Baird 1963). Following the 1959 field season, Don and Bill published an abstract with a preliminary list of the Wolfville tetrapod assemblage and a provisional correlation scheme for the Triassic of Nova Scotia and parts of New Jersey and the Connecticut Valley (Baird and Take 1959). In 1960, they spent considerable time prospecting outcrops of the Wolfville Formation at Burntcoat, near Noel, Hants County (Fig. 2), and found a maxilla that would later become the holotype of a third taxon of procolophonid parareptile, Haligonia bolodon (Sues and Baird 1998; NSM 996GF74.1), along with other fragmentary tetrapod remains.

Unfortunately the collaboration between Bill Take and Don did not continue after 1960. An underlying reason was a disagreement over the final disposition of the vertebrate fossils: Don proposed to deposit all the Triassic vertebrate fossils at the Nova Scotia Museum of Science in Halifax and take the Carboniferous material to Princeton. Take wanted all of the specimens returned to the care of his museum.

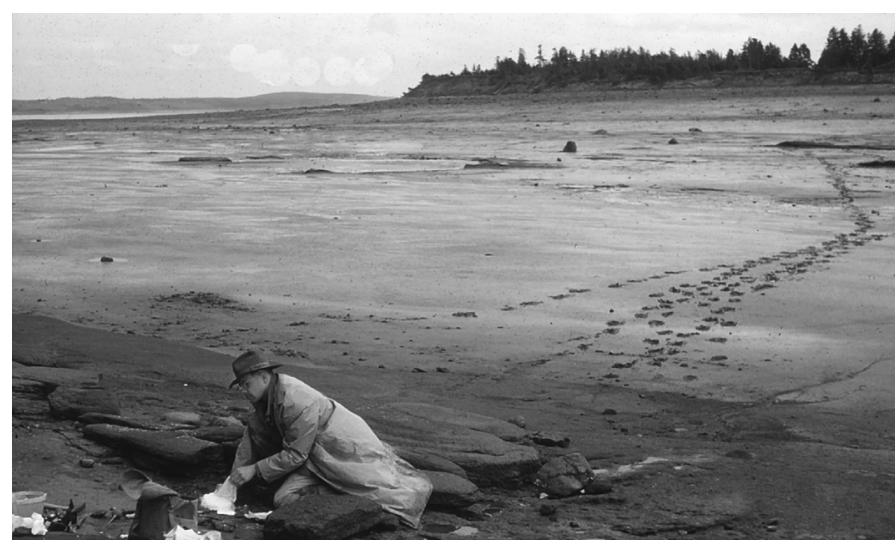

Figure 5. Don Baird recovering the partial skull of a Triassic procolophonid reptile (now the holotype of Scoloparia glyphanodon) at low tide near Boot Island (in the background), Kings County, 16 June 1959. Courtesy of A. Baird.

When Don returned to Halifax in 1963, he was dismayed to find many Triassic specimens still unwrapped, few labeled, and no cataloguing system in place. Mindful of the scientific value of this material, he arranged with the director of the museum a long-term loan of all fossils to Princeton for proper curation and study. Take, who was away at the time, never forgave Don for this action.

In July 1965, Bob Carroll, while collecting with Don, found a fragment of a very large dentary (YPM VPPU 019190) at Burntcoat, which proved to be the first record of a traversodont cynodont from North America. Hopson (1984) tentatively referred it to the Late Triassic genus Scalenodontoides, previously known only from Lesotho, but recognized it as a distinct species ?Scalenodontoides plemmyridon. Later, the recovery of a large upper molariform tooth by a field party led by one of us (H-DS) prompted a reassessment of this taxon and the naming of the new genus Arctotraversodon (Sues et al. 1992). Don continued to collect vertebrate fossils from the "Evangeline Member" of the Wolfville Formation until his last visit to Nova Scotia in 1985. Later two of us (H-DS and PEO) successfully continued this work, ably assisted for a number of years by the local fossil collector George P. Hrynewich.

Don also discovered an assemblage of fragmentary remains of tetrapods from the "Economy Member" of the Wolfville Formation near Lower Economy in Colchester County in 1966 (Baird 1986). This occurrence is distinctly different in faunal composition from the better-known tetrapod assemblage from the overlying "Evangeline Member" and may be significantly older, possibly as old as early Middle Triassic. This is based on the fact that in North America and Morocco tetrapod assemblages with only nonmetoposaurid temnospondyls are found in strata of Middle Triassic age and are overlain by Late Triassic strata with 
metoposaurids (Sues and Olsen, personal observations). However, in comparison with the well-dated tetrapod assemblages from the German Triassic, there are no taxa that actually constrain the age more precisely than Middle to early Late Triassic.

In October 1973, Don and one of us (PEO) were prospecting exposures in the Wolfville area when Don spotted a sandstone slab covered with natural casts of several three-toed, rather bird-like foot impressions associated with small hand imprints. Don realized immediately that this find belonged to a new ichnogenus that he had identified previously in the Newark and Gettysburg basins of New Jersey and Pennsylvania, based in part upon what he had described separately as Anchisauripus milfordensis and Grallator sulcatus in his doctoral dissertation (Baird 1957) and in part on material he had collected at Milford, New Jersey in the 1960s. Olsen and Baird (1986) later named this new ichnogenus Atreipus, and the Nova Scotian slab (YPM VPPU 021713 B) became the holotype of the new ichnospecies Atreipus acadianus. Don had coined the generic name in honor of Atreus Wanner, a school teacher from York, Pennsylvania, who had discovered a beautifully preserved set of these distinctive tracks in the Gettysburg basin nearly a century earlier (Wanner 1889). Olsen and Baird (1986) argued that either an early ornithischian dinosaur or a non-dinosaurian archosaur converging on ornithischians in the structure of its feet left the distinctive tracks of Atreipus. The track makers now are thought to have been close relatives of dinosaurs such as Silesauridae (Olsen et al. 2005), the first skeletal remains of which were only discovered quite recently (Irmis et al. 2007).

In August 1976, a field party comprising Don, PEO, and Princeton technician John R. "Jack" Horner (who would go on to become one of the world's leading experts on Cretaceous dinosaurs) made history when PEO discovered what would be the first unequivocal skeletal remains of dinosaurs known from the Maritimes. On a rainy August day, while prospecting exposures of the uppermost Triassic and lowermost Jurassic McCoy Brook Formation at Wasson Bluff near Parrsboro (Fig. 2), PEO collected numerous white, unusually large, angular bits of what appeared to be bone originating from a basalt-clastbearing sandstone bed between eolian sandstones. There was initially some doubt concerning the identity of these pieces because zeolite minerals often superficially resemble fossil bone and are abundant in the basalts, and bone had not been previously reported from this area. A few evenings later, however, they assembled the fragments into a threedimensional jigsaw puzzle that Don identified as a cervical vertebra of an early sauropodomorph ("prosauropod") dinosaur (YPM VPPU 022196). During two subsequent visits to the site, the field party collected a partial femur, some caudal vertebrae, and a phalanx from the foot, all of which belong to sauropodomorph dinosaurs. The Wasson
Bluff material is currently the oldest known skeletal material of dinosaurs from eastern North America. As Don would observe, however, Late Triassic tracks of dinosaurs from Nova Scotia predate these finds in geological age (Olsen et al. 1989, 2005). Don and PEO collected tetrapod footprints and fish from other latest Triassic localities in Nova Scotia, with Baird being the first to discover the important locality for semionotid fishes at Five Islands Provincial Park in 1976. Eldon George, in addition to his discoveries of Pennsylvanian fossils, also collected many excellently preserved footprints of dinosaurs and other reptiles from the McCoy Brook Formation, mostly at McKay Head and Blue Sac, both between Wasson Bluff and Five Islands.

Work in the 1980s by teams from Columbia and Harvard, with financial support from the National Geographic Society, made a concerted collecting effort at Wasson Bluff and discovered a diverse assemblage of latest Triassic to earliest Jurassic vertebrates from various facies representing fully terrestrial to aquatic depositional settings (Olsen et al. 1987, 1989, 2005; Shubin et al. 1991, 1994; Sues et al. 1994, 1996). One of the most common taxa is the small sphenodontian Clevosaurus bairdi, which Sues et al. (1994) named in Don's honor. During the next two decades, researchers from the Nova Scotia Museum of Natural History in Halifax and the Fundy Geological Museum in Parrsboro recovered additional sauropodomorph remains, including articulated partial skeletons. This material formed the subject of an unpublished Ph.D. dissertation by Timothy Fedak at Dalhousie University in Halifax. Unfortunately, tectonic deformation of these specimens renders their anatomical interpretation very difficult.

Don maintained an interest in the Triassic-Jurassic of Nova Scotia through the 1980s, although he did little additional collecting himself. During this time, PEO continued to bring footprint material to Princeton where Don worked on identifying it. One particular slab had an especially colorful history. Mark Anders, then a graduate student at Berkeley (now a professor at Columbia University), told PEO in the spring of 1984 that he had seen a slab bearing interesting tracks of Batrachopus at McKay Head. Together with Joseph Smoot (United States Geological Survey), Anders and PEO collected the block (now YPM PU 23631) in July 1984. This proved to be a difficult undertaking because the slab was very heavy, covered with mud, and far from the vehicles. There was still quite a bit of mud on the rock when it was hauled into Don's preparation room in Guyot Hall at Princeton. When Don cleaned off the slab with the tracks of Batrachopus he discovered a minute dinosaur trackway and photographed the best of its footprints. Eldon George subsequently told PEO that he had seen that slab, and had turned it over but not collected it. Thus he gets the credit for finding the slab, but Don deserves the credit for finding the dinosaur track. A photograph of a footprint appeared in Time in 1986 as 
part of the publicity generated by a press release from the National Geographic Society on the discoveries at Wasson Bluff (even though the block was collected at McKay Head.) It was labeled, "World's smallest dinosaur footprint".

\section{EPILOGUE}

In all, from his first field season in 1956 to his last in 1985, Donald Baird made 21 trips to Nova Scotia. After the first few years, he had identified promising collecting areas and had learned, sometimes the hard way, how to deal with the dramatic tidal changes in the Bay of Fundy that dictate collecting schedules and methods (Fig. 6). Among those who accompanied or joined Don in the field after 1960, in approximate chronological order, were Robert M. Salkin, Eugene S. Gaffney, Robert L. Carroll, Gerald R. Case, Robert M. Hunt, Jr., Robert R. Reisz, Edward S. Belt, Malcolm J. Heaton, PEO, R. William Selden, John R. Horner, Patrick Leiggi, and RWH. Specimens collected during these trips have been the subject of, or at least mentioned in, scores of papers (in addition to those already cited: Baird and Olsen 1983; Kjellesvig-Waering 1986). After Bob Carroll started his academic career at McGill University in 1964, he and his students would frequently join Don in Nova Scotia for fieldwork. This collaboration culminated in a detailed field guide for the Twenty-Fourth International Geological Congress that reviewed Devonian through Triassic localities in eastern Canada (Carroll et al. 1972).

The history of research on fossil vertebrates from Nova Scotia shows clearly the profound influence of Don's patient and painstaking work in the field and laboratory. With regard to fossil tetrapods alone, prior to Don's first trip to the province in 1956, the only skeletal remains known were those from Joggins and two specimens from the Albion Mine of Stellarton. By the end of his active career, numerous important localities for Carboniferous vertebrates were known, and the entirely new realm of early Mesozoic vertebrate paleontology had been opened in the province. Although Don himself did not find all the localities, his field parties were responsible for many discoveries and his relentless commitment to prospecting even the least fossiliferous exposures resulted in highly significant collections. Even after retirement, he continued to be an enthusiastic supporter of paleontological research in Nova Scotia, often as a reviewer of grant proposals for fieldwork or museum studies. Thanks to Don's deep devotion to the vertebrate paleontology in the province, Nova Scotia will be a premier source of data and insights for many years to come.

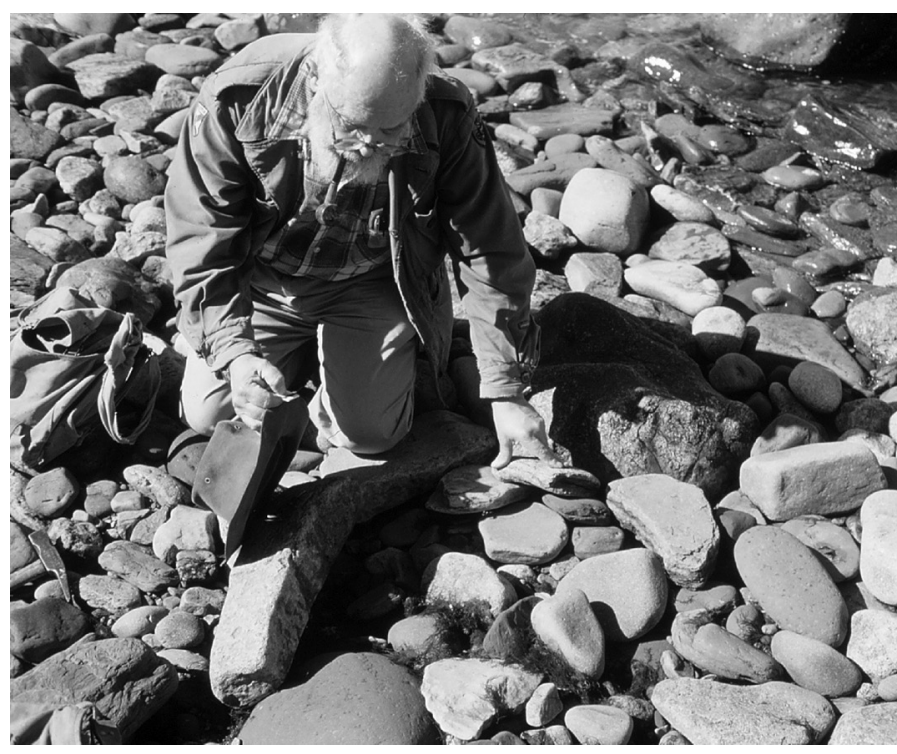

Figure 6. Don Baird employing the "burnt dope" technique (Baird 1978b) to collect the fin-spine of a ctenacanth shark at Grand Étang, Cape Breton Island, Nova Scotia, 7 September 1985. Don would liberally douse exposed fossils with diluted cellulose cement, which he would then set on fire. This process would leave a residual coating on the fossil and matrix, which then could be safely extricated in advance of rising tides. Collection of RWH.

\section{ACKNOWLEDGEMENTS}

First and foremost, we wish to acknowledge our late friend Donald Baird. Although he is the subject of this contribution, he also was our dear friend, teacher, tireless supporter, and treasured colleague. Andy Baird provided details on the Baird family history and kindly granted us use of some of the photographs reproduced herein. Eugene Gaffney offered his recollections of Don, and former Princeton students Michael Archer, David Parris, and Barbara Grandstaff furnished insights on Don's activities at Princeton. John Calder offered advice on Carboniferous stratigraphy in Nova Scotia. Andy Baird, Steven Madsen, editor Robert Fensome, and reviewers Robert Holmes and Kevin Padian provided helpful comments on drafts of the manuscript. We are indebted to all. 


\section{REFERENCES}

Baird, D. 1951. Latex molds in paleontology. Compass of Sigma Gamma Epsilon, 28, pp. 339-345.

Baird, D. 1954. Chirotherium lulli, a pseudosuchian reptile from New Jersey. Bulletin of the Museum of Comparative Zoology at Harvard College, 111, pp. 163-194.

Baird, D. 1955. Latex micro-molding and latex-plaster molding mixture. Science, 122, p. 202. http://dx.doi. org/10.1126/science.122.3161.202

Baird, D. 1957. Triassic reptile footprint faunules from Milford, New Jersey. Bulletin of the Museum of Comparative Zoology at Harvard College, 117, pp. 447520.

Baird, D. 1962a. A haplolepid fish fauna in the early Pennsylvanian of Nova Scotia. Palaeontology, 5, pp. 2229.

Baird, D. 1962b. A rhachitomous amphibian, Spathicephalus, from the Mississippian of Nova Scotia. Breviora, 157, pp. $1-10$.

Baird, D. 1963. Rhynchosaurs in the Late Triassic of Nova Scotia. Geological Society of America Special Paper, 73, p. 107.

Baird, D. 1978a. Studies on Carboniferous freshwater fishes. American Museum Novitates, 2641, pp. 1-22.

Baird, D. 1978b. The burnt dope technique and other intertidal ploys. The Chiseler, 1, pp. 16-17.

Baird, D. 1986. Middle Triassic herpetofauna in Nova Scotia. Friends of the Triassic Newsletter, 5, p. 10.

Baird, D. 1997. Joseph T. Gregory Award - response by Donald Baird. Society of Vertebrate Paleontology News Bulletin, 169, pp. 23-25.

Baird, D. and Carroll, R.L. 1967. Romeriscus, the oldest known reptile. Science, 157, pp. 56-59. http://dx.doi. org/10.1126/science.157.3784.56

Baird, D. and Olsen, P.E. 1983. Late Triassic herpetofauna from the Wolfville Fm. of the Minas Basin (Fundy Basin), Nova Scotia, Can. Geological Society of America Abstracts with Programs, 15, p. 122.

Baird, D. and Take, W.F. 1959. Triassic reptiles from Nova Scotia. Geological Society of America Bulletin, 70, pp. 1565-1566.

Beaumont, E.H. 1977. Cranial morphology of the Loxommatidae. Philosophical Transactions of the Royal Society of London, B, 280, pp. 29-101. http://dx.doi. org/10.1098/rstb.1977.0099

Beaumont, E.H. and Smithson, T.R. 1998. The cranial morphology and relationships of the aberrant Carboniferous amphibian Spathicephalus mirus Watson. Zoological Journal of the Linnean Society, 122, pp. 187-209. http://dx.doi.org/10.1111/j.1096-3642.1998. tb02529.x

Berman, D.S. 1978. Ctenospondylus ninevehensis, a new species (Reptilia, Pelycosauria) from the Lower Permian
Dunkard Group of Ohio. Annals of Carnegie Museum, 41, pp. 493-514.

Calder, J.H., Baird, D., and Urdang, E.B. 2004. On the discovery of tetrapod trackways from PermoCarboniferous redbeds of Prince Edward Island and their biostratigraphic significance. Atlantic Geology, 40, pp. 217-226.

Calder, J.H., Gibling, M.R., Scott, A.C., Davies, S.J., and Hebert, B.L. 2006. A fossil lycopsid forest succession in the classic Joggins section of Nova Scotia: paleoecology of a disturbance-prone Pennsylvanian wetland. Geological Society of America Special Paper, 399, pp. 169-195.

Camp, C.L. 1958. Memorial to Frank Elmer Peabody (1914-1958). Proceedings Volume of Geological Society of America, Annual Report for 1958, pp. 165-167.

Carroll, R.L. 1967. A limnoscelid reptile from the Middle Pennsylvanian. Journal of Paleontology, 4, pp. 1256-1261.

Carroll, R.L. 1969. A Middle Pennsylvanian captorhinomorph, and the interrelationships of primitive reptiles. Journal of Paleontology, 43, pp. 151-170.

Carroll, R.L., Belt, E.S., Dineley, D.L., Baird, D., and McGregor, D.C. 1972. Vertebrate paleontology of eastern Canada. Guidebook for Field Excursion A59, TwentyFourth International Geological Congress, Montreal, 113 p.

Clack, J.A. 2012. Gaining ground: the origin and evolution of tetrapods. Second edition. Indiana University Press, Bloomington, $523 \mathrm{p}$.

Clack, J.A. and Carroll, R.L. 2000. Early Carboniferous tetrapods. In Amphibian biology. Vol. 4: Palaeontology. Edited by H. Heatwole and R.L. Carroll. Surrey Beatty \& Sons Pty Ltd, Chipping Norton, NSW, pp. 1030-1043.

Colbert, E.H. 1982. Alfred Sherwood Romer 1894-1973. National Academy of Sciences Biographical Memoirs, 53, pp. 265-294.

Dawson, J.W. 1863. Air-breathers of the Coal Period: a descriptive account of the remains of land animals found in the Coal Formation of Nova Scotia with remarks on their bearing on theories of the formation of coal and of the origin of species. Dawson Brothers, Montreal, $81 \mathrm{p}$.

Dawson, J.W. 1882. On the results of recent explorations of erect trees containing animal remains in the Coalformation of Nova Scotia. Philosophical Transactions of the Royal Society of London, 173, part 2, pp. 621-659. http://dx.doi.org/10.1098/rstl.1882.0013

Dawson, J.W. 1894. Synopsis of the air-breathing animals of the Palaeozoic in Canada up to 1894. Proceedings and Transactions of the Royal Society of Canada, section 4, 7 , pp. 71-88.

Godfrey, S.J. 1989. The postcranial skeletal anatomy of the Carboniferous tetrapod Greererpeton burkemorani Romer, 1969. Philosophical Transactions of the Royal Society of London B, 323, pp. 75-133. http://dx.doi. org/10.1098/rstb.1989.0002 
Godfrey, S.J. and Holmes, R. 1995. The Pennsylvanian temnospondyl Cochleosaurus florensis Rieppel, from the lycopsid stump fauna at Florence, Nova Scotia. Breviora, 500, pp. 1-25.

Holmes, R., Godfrey, S.J., and Baird, D. 1995. Tetrapod remains from the late Mississippian Pomquet Formation near Grand Étang, Nova Scotia. Canadian Journal of Earth Sciences, 32, pp. 913-921. http://dx.doi.org/10.1139/e95076

Hook, R.W. and Baird, D. 1986. The Diamond Coal Mine of Linton, Ohio, and its Pennsylvanian-age vertebrates. Journal of Vertebrate Paleontology, 6, pp. 174-190. http:// dx.doi.org/10.1080/02724634.1986.10011609

Hook, R.W. and Baird, D. 1993. A new fish and tetrapod assemblage from the Allegheny Group (late Westphalian, Upper Carboniferous) of eastern Ohio, U.S.A. In New research on Permo-Carboniferous faunas. Compiled by $\mathrm{U}$. Heidtke. Pollichia-Buch 29, Bad Dürkheim, pp. 143-154.

Hopson, J.A. 1984. Late Triassic traversodont cynodonts from Nova Scotia and southern Africa. Palaeontologia africana 25, pp. 181-201.

Irmis, R.B., Parker, W.G., Nesbitt, S.J., and Liu J. 2007. Early ornithischian dinosaurs: the Triassic record. Historical Biology, 19, pp. 3-22. http://dx.doi. org/10.1080/08912960600719988

Kjellesvig-Waering, E.N. 1986. A restudy of the fossil Scorpionida of the world. Palaeontographica Americana, 55, pp. 1-287.

Klembara, J. 1985. A new embolomerous amphibian (Anthracosauria) from the Upper Carboniferous of Florence, Nova Scotia. Journal of Vertebrate Paleontology, 5, pp. 293-302. http://dx.doi.org/10.1080/02724634.1985 .10011867

Laurin, M. and Reisz, R.R. 1992. A reassessment of the Pennsylvanian tetrapod Romeriscus. Journal of Vertebrate Paleontology, 12, pp. 524-527. http://dx.doi.org/10.1080/ 02724634.1992.10011478

Lull, R.S. 1904. Fossil footprints of the Jura-Trias of North America. Memoirs of the Boston Society of Natural History, 5, pp. 461-557.

Lyell, C. and Dawson, J.W. 1853. On the remains of a reptile (Dendrerpeton Acadianum, Wyman and Owen) and of a land snail discovered in the interior of an erect fossil tree in the coal measures of Nova Scotia. Quarterly Journal of the Geological Society of London, 9, pp. 58-63. http:// dx.doi.org/10.1144/GSL.JGS.1853.009.01-02.19

Milner, A.R. 1982. A small temnospondyl amphibian from the Lower Pennsylvanian of Nova Scotia. Journal of Paleontology, 56, pp. 1302-1305.

Olsen, P.E. and Baird, D. 1986. The ichnogenus Atreipus and its significance for Triassic biostratigraphy. In The beginning of the Age of Dinosaurs: faunal change across the Triassic-Jurassic boundary. Edited by K. Padian. Cambridge University Press, New York, pp. 61-87.
Olsen, P.E., Shubin, N.H., and Anders, P.E. 1987. New Early Jurassic tetrapod assemblages constrain Triassic-Jurassic tetrapod extinction event. Science, 237, pp. 1025-1029. http://dx.doi.org/10.1126/science.3616622

Olsen, P.E., Schlische, R.W., and Gore, P.J.W. 1989. Tectonic, depositional, and paleoecological history of early Mesozoic rift basins, eastern North America. 28th International Geological Congress, Field Trip Guidebook T351. American Geophysical Union, Washington, DC, $174 \mathrm{p}$.

Olsen, P.E., Whiteside, J.H., and Fedak, T. 2005. Field Trip A7: The Triassic-Jurassic faunal and floral transition in the Fundy Basin, Nova Scotia. Geological Association of Canada, Mineralogical Association of Canada, Canadian Society of Petroleum Geologists, Canadian Society of Soil Sciences Joint Meeting, Halifax, May 2005. AGS Special Publication Number 26, $53 \mathrm{p}$.

Owen, R. 1854. On a fossil reptilian skull embedded in a mass of Pictou coal from Nova Scotia. Quarterly Journal of the Geological Society of London, 10, pp. 207-208. http://dx.doi.org/10.1144/GSL.JGS.1854.010.01-02.16

Peabody, F.E. 1948. Reptile and amphibian trackways from the Lower Triassic Moenkopi Formation of Arizona and Utah. University of California Publications, Bulletin of the Department of Geological Sciences, 27, pp. 295-468.

Reisz, R.R. 1972. Pelycosaurian reptiles from the Middle Pennsylvanian of North America. Bulletin of the Museum of Comparative Zoology, Harvard University, 144, pp. 27-62.

Rieppel, O. 1980. The edopoid amphibian Cochleosaurus from the Middle Pennsylvanian of Nova Scotia. Palaeontology, 23, pp. 143-149.

Romer, A.S. 1930. The Pennsylvanian tetrapods of Linton, Ohio. Bulletin of the American Museum of Natural History, 59, pp. 77-147.

Romer, A.S. 1958. An embolomere jaw from the midCarboniferous of Nova Scotia. Breviora, 87, pp. 1-8.

Rygel, M.C., Calder, J.H., Gibling, M.R., Gingras, M.K., and Melrose, C.S.A. 2006. Tournaisian forested wetlands in the Horton Group of Atlantic Canada. Geological Society of America Special Paper, 399, pp. 103-126.

Sarjeant, W.A.S. and Mossman, D.J. 1978. Vertebrate footprints from the Carboniferous sediments of Nova Scotia: a historical review and description of newly discovered forms. Palaeogeography, Palaeoclimatology, Palaeoecology, 23, pp. 279-306. http://dx.doi. org/10.1016/0031-0182(78)90097-4

Shubin, N.H., Crompton, A.W., Sues, H.-D., and Olsen, P.E. 1991. New fossil evidence on the sister-group of mammals and early Mesozoic faunal distributions. Science, 251, pp. 1063-1065. http://dx.doiorg/10.1126/ science.251.4997.1063

Shubin, N.H., Olsen, P.E., and Sues, H.-D. 1994. Early Jurassic small tetrapods from the McCoy Brook Formation 
of Nova Scotia. In In the shadow of the dinosaurs: early Mesozoic tetrapods. Edited by N.C. Fraser and H.-D. Sues. Cambridge University Press, New York, pp. 242-250.

Smithson, T.R. 1982. The cranial morphology of Greererpeton burkemorani Romer (Amphibia: Temnospondyli). Zoological Journal of the Linnean Society, 76, pp. 29-90. http://dx.doi.org/10.1111/j.1096-3642.1982.tb01955.x

Smithson, T.R., Wood, S.P., Marshall, J.A.E., and Clack, J.A. 2012. Earliest Carboniferous tetrapod and arthropod faunas from Scotland populate Romer's Gap. Proceedings of the National Academy of Sciences, 109, pp. 4532-4537. http://dx.doi.org/10.1073/pnas.1117332109

Sues, H.-D. and Baird, D. 1998. Procolophonidae (Reptilia: Parareptilia) from the Upper Triassic Wolfville Formation of Nova Scotia, Canada. Journal of Vertebrate Paleontology, 18, pp. 525-532. http://dx.doi.org/10.1080/ 02724634.1998.10011079

Sues, H.-D., Hopson, J.A., and Shubin, N.H. 1992. Affinities of ?Scalenodontoides plemmyridon Hopson, 1984 (Synapsida: Cynodontia) from the Upper Triassic of Nova Scotia. Journal of Vertebrate Paleontology, 12, pp. 168171. http://dx.doi.org/10.1080/2724634.1992.10011447

Sues, H.-D., Shubin, N.H., and Olsen, P.E. 1994. A new sphenodontian (Lepidosauria: Rhynchocephalia) from the McCoy Brook Formation (Lower Jurassic) of Nova Scotia, Canada. Journal of Vertebrate Paleontology, 14, pp. 327-340. http://dx.doi.org/10.1080/02724634.1994.1 0011563

Sues, H.-D., Shubin, N.H., Olsen, P.E., and Amaral, W.W. 1996. On the cranial structure of a new protosuchid (Archosauria: Crocodyliformes) from the McCoy Brook Formation (Lower Jurassic) of Nova Scotia, Canada. Journal of Vertebrate Paleontology, 16, pp. 34-41. http:// dx.doi.org/10.1080/02724634.1996.10011281

Utting, J., Keppie, J.D., and Giles, P.S. 1989. Palynology and age of the Lower Carboniferous Horton Group, Nova Scotia. Geological Survey of Canada Bulletin, 396, pp. $117-143$.

Wanner, A. 1889. The discovery of fossil tracks, algae, etc., in the Triassic of York County, Pennsylvania. Pennsylvania Geological Survey Annual Report, 1887, pp. 21-35.

Watson, D.M.S. 1926. Croonian Lecture - The evolution and origin of the Amphibia. Philosophical Transactions of the Royal Society of London B, 214, pp. 189-257. http:// dx.doi.org/10.1098/rstb.1926.0006

Editorial responsibility Robert A. Fensome 